\title{
From Expertise to Effectiveness: A Content Analysis of Islamic State Legitimation
}

\section{Strategies}

\section{Scovia Aweko}

\section{Purdue University}

The U.K., U.S., and Canada have all sponsored countering violent extremism (CVE) campaigns focused on preventing terrorist recruitment from the West (Mitts, forthcoming). However, individuals in the Global North are still joining terrorist groups. Studies have shown that many Islamic State foreign fighters came from high-income countries with high levels of economic development, low levels of income inequality, and well-developed social and political institutions. This shows that despite the best efforts of the CVE campaigns to prevent participation in terrorism, individuals will still join such groups (Benmelech and Klor, 2018). Additionally, given the abrogating representation of terrorism in the media and the stigma that surrounds terrorism, it is difficult to see why individuals would want to join terrorist groups.

In this paper, I ask: How does the Islamic State present itself as legitimate in its online English language magazines? Studying ways in which the Islamic State makes claims to legitimacy will inform counter terrorism efforts, especially those focusing on de-radicalization and recruitment. I briefly summarize the debate on rebel governance and "govermentality," legitimacy and legitimation. I then present the strategies with which the Islamic State has made claims to legitimacy and my research design. I will end by presenting my results and an analysis of those results. 
Past research on the reasons why individuals join rebel groups and in particular terrorist groups given the high cost of member ship in such groups have led to multiple differing answers. Apart from coercion an abduction of children to join rebel groups, many individuals choose to voluntary join rebel groups. Some of the reason given to explain why individuals rebel include institutional weaknesses of the state that inhibit the ability of groups to settle grievances, economic deprivation that leads to economic and political inequalities (Fearon and Laitin, 2003:77; Boix, 2008:392; Cederman et al, 2011Kuhn \& Weidmann, 2015).

These scholarships on recruitment focus on a localized process. However, the advent of the internet and social media has made it relatively easy for violent organizations to recruit beyond local boundaries (Benmelech and Klor, 2018; Mitts, forthcoming; Bloom, Tiflati and Horgan, 2019). My work adds to that of those who look at how terrorist groups outside the western world are able to recruit and convince people to commit terrorist acts. I do this by looking at legitimation in Islamic State English language propaganda magazines. I contribute to the legitimation literature by looking at the ways that a transnational rebel organization with a transnational target audience seeks to create a "one size fit all" narrative for its multiple audiences. Backed by Islamic fundamentalist ideology, the Islamic State was able to create an image of itself that appealed to multiple audiences at the same time.

\section{The Islamic State}

In June of 2014, the world was taken by surprise when a little-known Al-Qaeda affiliate announced a caliphate (Byman, 2016; CNN, 2019). Although it was well known that a terrorist group known as the Islamic State was brutally making progress and gaining territory in Iraq and 
heading towards Syria, the group's declaration of a caliphate still caught many world leaders off guard. No terrorist group had ever attempted to amass territory let alone make overt claims to that territory. More surprising though, was that the Islamic State did not declare a state but something bigger and above the state, a caliphate. This caliphate would erase existing borders and create new governing structures. This declaration was further substantiated by the organization performing the functions of states while continuing to have military victories against state armies (Byman, 2016).

Daniel Byman argues the different names with which the Islamic State identified itself over time shows the progression of its interests. The Islamic State started off as Al-Qaeda in Iraq with the intentions of taking over government authority, then it expanded beyond Iraq to Syria and became Islamic State in Iraq and Syria. From there it became the Islamic State with aspirations of creating a Muslim caliphate. With the change in names, the Islamic State projected its organizational goal of being transnational without limiting itself to taking over territory in the previous two countries or any particular country for that matter (Byman, 2015:163-164). The goal of the Islamic State was then to transcend borders and establish a universal empire only comparable to the Catholic church (empire) today.

Scholars who have written about the Islamic State have focused on the way that the organization took advantage of the internet and social media for recruitment and radicalization. However, these schools have barely investigated the ways that the organization makes claims of and asserts its legitimacy in these propaganda items, as another strategy for recruitment and radicalization.

\section{$\underline{\text { Rebel Governance and the Islamic State }}$}


Governance and government are functions that are predominantly viewed as the sole responsibility of state authority and such the prerogative of state governments. Violent nongovernmental organizations like rebel groups and terrorist groups are often left out of the discussion of governance even though these groups often perform governance (Arjona, Kasfir \& Mampilly, 2015; kasfir,2015; Podder,2014). Mampilly defines rebel governance as "the development of institutions, and importantly, informal and formal norms and rules of behavior, by insurgents that regulate civilian social, economic, and political life" (Arjona, Kasfir \& Mampilly, 2015: 77). For something to be called rebel governance, there must be "territorial control, a residential population and violence or the threat of violence" (Arjona, Kasfir \& Mampilly, 2015). Rebel governance happens within gaps created by state weakness often during times of civil conflict. As armed groups seeking to prove their capability to target audiences, violent organizations take on more non-violent means of governance like the provision of services (Arjona, Kasfir \& Mampilly, 2015: 77). One of the most notable byproducts of rebel governance is legitimacy. As violent groups continue to administer their newly conquered territory, it soon becomes apparent that "formal structures" are not a sufficient tool of governance and therefore will "deploy symbolic processes to give meaning to [their] actions" (Arjona, Kasfir \& Mampilly, 2015:77).

When talking about rebel governance, many readers are inclined to turn to Charles Tilly's war-making as state-making. However, rebel groups of today do not fit the framework that Tilly set. For Tilly (1985), the path to statehood starts with war-making, which then leads to state making through extraction. Tilly defined war making as the process of "eliminating or neutralizing rivals outside of the territories in which [a state] has clear and continuous priority as wielders of force" (Tilly, 1985:181). Furthermore, Tilly defines state making as "eliminating or neutralizing rivals 
inside those territories" and extraction as "acquiring the means of carrying out war making and state making" (Tilly, 1985:181).

Mampilly however argues that state formation is an insufficient lens for explaining rebel governance (Mampilly, 2011). Unlike the trajectory of "war-making to state-making" that Tilly writes of, many states outside of the European context failed to follow this path. Mampilly eschews the notion that "service provision by rebels may represent embryonic state building" and the idea that "contemporary rebel groups driven by economic self-interest may actually be replicating the dynamics that gave rise to the modern nation-state" (Mampilly, 2011:31). Mampilly states that scholars limit their analysis by seeing rebel governance only through the lens of state making (Mampilly, 2011). What differentiates state and rebel governance is recognition from other states in the system (Arjona, Kasfir \& Mampilly, 2015). This recognition sets the tone for how these different entities govern (Arjona, Kasfir \& Mampilly, 2015). Weber's idea of legal-rational authority which stems from Western norms of bureaucracy and codifying behavior under a system of laws. States that are considered legitimate under the legal-rational category have to follow or implement Western ideals of bureaucracy, institutions and laws and these institutions have to be “established in a manner recognized to be legal" (Weber, 1945).

Another reason that rebel governance should not be equated with "embryonic statemaking" is that "the state does not disappear but rather remains the premier competitor and threat to any non-state produced political and social order" (Mampilly, 2011:37). Rebel groups in their newly conquered territory lack the resources and capacity of states that they compete with. For this reason, "states can penetrate rebel-controlled territories and disrupt any internal political or processes" (Mampilly, 2011:37) 
The threat that rebel organizations and rebel governance pose to states and the international system of statehood provides an obstacle to those groups gaining international recognition as "equals" in the eyes of other states. Mampilly argues that "the primacy of the state system, does not allow for much variation from the dominant paradigm that for every piece of territory, a specific state is deemed sovereign" (Mampilly, 2011:37). Given that all territory on earth is claimed by sovereign states, for a group like the Islamic State to own territory, they would have to take this from an existing state. The capture of sovereign territory from states by rebel groups leaves states vulnerable to the possibility of losing their sovereignty, power and standing in the international system.

For the reasons discussed above rebel groups that perform governance often choose to refrain from "transitioning to statehood" only to focus on "retaining their empirical gains without risking everything” (Mampilly, 2011:37). The Islamic State went against this norm. The Islamic State with its "cross-border" territory made claims not only to statehood but empire under the pretext of fulfillment of the promise of an "ummah" (worldwide Muslim nation). The audacious proclamation of an Islamic Caliphate by the Islamic State drew "rightful" attention as this was highly irregular in modern state relationships.

The Islamic State envisioned "a state where the Arab and non-Arab, the white man and black man, the easterner and westerner are all brothers. It is a Khilafah that gathered the Caucasian, Indian, Chinese, Shami, Iraqi, Yemeni, Egyptian, Maghribi (North African), American, French, German, and Australian. Allah brought their hearts together, and thus, they became brothers" (Dabiq, Issue 1). This is a state where race and nationality does not matter. The Islamic State sought to create a cosmopolitan environment where only religion mattered. 
There are more similarities between terrorist groups and rebel groups than differences, What set apart the Islamic State from other rebel groups found during civil wars is that it is a radical Islamic group that is driven by the idea of jihad. However, when it comes governance, the ways by which the Islamic State governs its territory and its constituents is not institutionally different from other rebel groups.

The Islamic State sought to create a utopian Muslim caliphate governed under sharia law. This Utopian Muslim caliphate appealed to Muslims who were being persecuted and subjugated in Western and Muslim states allied with the West (Dabiq, Issue 3). As the self-appointed defenders and liberators of Muslims from subjugation, the Islamic State then created governing institutions infirmed by sharia law. Those living under Islamic state territory were required to pay "zakat" a form of taxation that is intended to redistribute wealth under Islamic law (Atwan, 2015; Dabiq, Issue 4). The Islamic State also pledged to take care of the vulnerable in society i.e the elderly, sick and children. In order to do this, the organization had to establish hospitals and schools and "social security" system that would be able to take care of these vulnerable populations (Atwan, 2015; Dabiq, Issue 4). The Islamic State had a functioning judiciary under the mandate of sharia law and went as far as minting its own coins, establishing a market economy by taking advantage of the oil fields it had control over (Atwan, 2015; Dabiq, Issue 4).

Islamic State governance was defined by its challenge of the current system of statehood. With the vast territory under its control and many more smaller rebel groups and individuals pledging allegiance to the organization, the Islamic State managed to operate and govern transnationally. The Islamic State's target audience was western foreign fighters. The reason for this is because members of the Islamic State were rebelling against western crusader armies and their middle eastern allies. The most effective blow that they could inflict on western nations was 
to radicalize their own citizens under the pretext of fulfillment of hijra and jihad. In Issue three of Dabiq, it is written that the perfect individual to perform hijra "lives in the West amongst the kuffär for years, spends hours on the Internet, reads news and posts on forums" which sets the tone for who the organization's target audience is (Dabiq, Issue 2:27).

The focus on Western foreign fighters means that the "native" population living under Islamic State territory were secondary. Whereas the Islamic State could use coercion and violence to recruit those under its conquered territory, the group had to incorporate elaborate ways of legitimation and governance to recruit western foreign fighters. The promise of living in an organized society not so structurally different, though ideologically different from the West is a recurring theme in Islamic State propaganda magazines. Pleasing the Western foreign fighter became central to the Islamic State's governance structure and activities taken to legitimate the organization. The Islamic State used multiple media to govern its far flung constituents and one that is the focus of this paper is the organization's English language magazines.

\section{Legitimacy}

Legitimacy is defined as the "generalized perception or an assumption that the actions of an entity are desirable, proper, or appropriates within some socially constructed system of norms, values, beliefs and definitions" (Suchman, 1995:574). Unlike other forms of power like coercion and self-interest, legitimacy requires voluntary compliance from those who it is subjected upon (Hurd, 1999; Symons 2011). However, voluntary compliance can only come after the internalization and recognition of an entity's appropriateness with the norms, values, and interests upon whom it is imposed (Suchman, 1995).

For some international relations (IR) scholars, in order for a state to be legitimate, it has to be moral and just. According to Simmons (1999: 744), a moral state "acquires legitimacy by 
having its operations consented to by enough residents of its territory." If those within the state's territory hold the belief that the state, its institutions, and representatives ought to be obeyed, then we can say that that state is legitimate (Hurd, 1999; Simmons, 1999). The legitimacy of a state is then rested upon the consent and obedience of its constituents. However, Applbaum (2010: 218) dismisses the premise that consent is required for legitimacy. Applbaum argues that indeed legitimate authority can be targeted to a certain group or issue area in that "legitimacy can be restricted in scope," (Applbaum, 2010:223). I argue that it is thus not as important that those conquered within Islamic State territory do not consent to its legitimate authority; what is more important is that the Islamic State's target audience, foreign fighters and recruits, consent to the organization's legitimate authority.

With the declaration of a caliphate, the Islamic State sought to "bring all the lands of Islam under its control" and to become the sole representative of Muslim people all over the world (Pollard et al, 2015). In this sense, the Islamic State establishes a global public for its domination. The Islamic State had two main audiences: those within its conquered territory and the foreign fighters or recruits who ascribe to the organization's ideology and pledge allegiance to it. However, this raises questions of legitimate domination. For Steffek, "international domination is entered into voluntarily" and those who claim international domination "govern clearly circumscribed areas," (Steffek, 2003:259).S The Islamic State presents an unusual case where the target constituents of the group are not the local people living in its conquered territory. The Islamic State's main target audience was the collective Muslim population around the world, specifically those who are willing to put everything aside to join and fight with the Islamic State. The local population within Islamic State territory were incidental to the territorial gains of the organization. This set the Islamic State apart from other rebel groups that focus on local 
populations as the Islamic State went after strategic territory and not strategic populations (Duyvesteyn 2017; Terpstra \&Frerks 2017; Borch \& Stuvoy 2008).

As such, I argue in this paper that the Islamic State's main audience were its foreign fighters and recruits, who are global rather than local. The Islamic State thus acted like the Catholic Church whose global center is at the Vatican, home to its governing and institutional structures. However, the people who substantiate the legitimacy of the Catholic Church, the Catholics, are scattered all over the world rather than concentrating within Vatican City alone. The Vatican projects a universal legitimate authority beyond its territorial base to a global audience that pledges allegiance to the Church (Ryall, 2001). Just like the Vatican, the Islamic State governed more than just a physical territory, even though it relied on territory for its power. For much of its history, the Catholic Church relied on its material power to maintain control over its territorial empire. Only recently has its material power become less relevant to its pursuits.

Just as the Vatican governs global Catholicism, the Islamic State sought to govern its version of Islam. By claiming to be the foremost authority on Islam, just like the Vatican is the foremost authority on Catholicism, the Islamic State projected itself as a supranational entity that is defined not only by its territory, but its ability to govern Islam and Muslims worldwide. Nonetheless, the Islamic State lacks the reputation of the Catholic Church. The Catholic Church is considered both a legitimate religious organization and pollical actor with the Holy See having an observer status within the United Nations.

. Due to the lack of recognition of its legitimacy from those within its territory and state authorities, the Islamic State engaged in self-legitimating practices targeted at those outside of the state, especially foreigners who would serve as potential recruits into the ranks of the organization's military apparatus. The goal of the Islamic State was to set up an Islamic Caliphate 
however, group's modus operandi guaranteed that they continue to be labeled merely as a terrorist organization

The imminent threat that the Islamic State presents to nation-states is one of the main reasons that nation-states do not recognize its statehood. For Sullivan and Bunker (2002: 42), the threat that groups like the Islamic State pose is "half-political, half-criminal," which exists in a "failed-state environment" and therefore creates conditions for a conflict that is "not war" but also "not-crime." Groups like the Islamic state undertake a myriad of activities that are both criminal and political in nature-This characteristic then makes it hard to classify them wholly as criminal or political or both.

\section{$\underline{\text { Legitimation }}$}

Given that legitimacy stems from recognition of an entity's right to rule, groups that want to appear legitimate have to actively cultivate this legitimacy. The act of cultivating legitimacy is often referred to as legitimation. Duyvesteyn (2017: 674) defines the legitimation process as "an action or series of actions e.g. speech, writing, ritual, display whereby people justify to themselves or others the actions they are taking and the identities they are expressing or claiming." Selflegitimation by rebel groups is situated around the identity and narrative of the group and providing a clear "other" who become the designated enemies of the group (Borch \& Stuvoy, 2011). The most prominent ways that rebel groups perform self-legitimation include "symbolic repertoires such as traditions and cultures, communal myth symbol, established enemy images and socioeconomic and political aspirations of a local community; and performance legitimacy which includes charisma, credibility through sacrifice, patrimonial loyalty, output in the shape of social contract and formal procedures" (Duyvesteyn , 2017: 678). 
Furthermore, for a government to be legitimate, there must be a "rational exchange of arguments, which eventually arrive a conclusion in the form of agreement" (Steffek, 2003:263). The Islamic State took advantage of free social media platforms like Twitter and YouTube to disseminate information about the group and recruit new members. The information on Twitter, YouTube and other open social media forums were the first step in the sequence of radicalization and recruitment. The final steps of recruitment happened in the chatrooms of encrypted social media platforms like Telegram and WhatsApp which makes it harder for government officials to monitor the conversations that happen on there (Mitts, 2018).

The assumption that precedes arguments for deliberative democracy is that all citizens have the capacity and the willingness to participate in deliberation. However, Sanders (1997: 356) argues that "the average human is more likely to yield more to prejudice and manipulation than to rational argument. If this is true, then recruitment chatrooms are fertile grounds for this manipulation. In addition, many people seek online communities that reaffirm their beliefs than those who disagree with them.

However, it is unclear the amount of deliberation or discussion that happened in these chatrooms outside sharing radicalizing information and providing instructions on what steps should be taken to become a member. For example, People go on social media not to have deliberative discussions, but to find a niche society that reaffirms their existing views (DeCilia, 2019). For Scudder (2019), deliberation goes beyond including differing opinions in a discussion. Deliberation involves uptake, which Scudder defines as "the fair consideration of the arguments and perspectives that citizens share in deliberation" (Scudder, 2019:1). Scudder (2019:1) continues to argue that uptake is what "ensures that citizens have a say in the laws to which they are held." That said, deliberation is often associated with democracy and is a fundamental requirement of a 
democratic regime/state. The Islamic State made no claims to democracy and therefore does not need deliberation over its policies and practices from constituents to be a legitimate state. In fact, there are many legitimately recognized states today that do not meet this requirement of legitimacy and work to oppress and silence dissenters.

Before legitimating themselves to the wider public, the leaders of a rebel organization must first gain legitimacy within the group. Self-legitimation within the group involves "a variety of rituals, rhetoric, and dramatizations" that is meant to distinguish members of the group from the rest of society (Borch \& Stuvoy, 2011: 99). These practices are meant to be a first step in formulating group identity. In this regard, rebel groups like the Islamic State are similar to nonstate actors such as gangs, mafias and cartels that perform extensive rituals of initiation for new recruits (Varese, 2018; Flanigan, 2012; Sullivan and Bunker, 2018).

After self-legitimation within the group, the organization can then extend this quest for legitimacy to an external audience, particularly those living within their territories. However, in the case of the Islamic State, this would be those the Muslim population that they claim to represent. Given the nature of the practices and brutality of rebel groups, Weber's legal-rational form of legitimacy is no longer -possible (Terpstra and Frerks, 2017).

Terpstra and Frerks provide five other strategies that rebel groups use to legitimate themselves. First, rebel groups often claim to "represent the socio-economic and political aspirations of a community" (Terpstra and Frerks, 2017:285). ). Rebel groups also form themselves as a result of discontent with the elite seek to change the way they are governed, when the elites of a community are seen as unrepresentative and unresponsive to the needs of the people. For the Islamic State, these elites include Western forces like the United State and regional elites in countries like Jordan, Syria, and Iraq. Second, rebel groups create a clear enemy image and outside 
threats. Having an enemy validates the actions of the group and also creates feelings of solidarity within the larger community that they seek represent (Terpstra and Frerks, 2017:285).

Third, the charisma of the leader of the group like charismatic legitimacy according to Weber is a stand-alone type of legitimacy that comes from certain qualities that an individual harbors (Terpstra and Frerks, 2017:285). However, in the case of the Islamic State, charismatic legitimacy is borrowed from religious-moral authority; therefore, the Islamic State's charismatic legitimacy does not exist as a stand-alone form of legitimacy, it is embedded in borrowed religious and moral legitimacy. We see an example of this embeddedness of moral legitimacy and charisma with the head of the Catholic Church, the Pope. The Pope does not have secular charismatic legitimacy, instead his is embedded in religious legitimacy. This charismatic-moral legitimacy is not sufficient in legitimating the statehood of the Islamic State. Spencer (1970:125) argues that charismatic authority in its pure form is "unbound by norms"

The fourth strategy of legitimation is the willingness and readiness of the group members to lay down their lives for the cause of the group (Terpstra and Frerks, 2017:285). For the Islamic State, this strategy is substantiated by the appeals of martyrdom that comes as a result of fighting for a religious cause. Fifth, the group makes claims to communal myth-symbol complexes and popular belief systems, traditions and cultures (Terpstra and Frerks, 2017:285). For the Islamic State, this comes from the fact that the caliphate they have established was predicted by the Quran, as the group uses Islamic law within its territory, it advances monotheism and advocates for Muslim unity (Byman, 2016).

\section{Research Design}

The data comes from the issues of Dabiq and Rumiyah, the Islamic State propaganda magazines. These magazines can be downloaded from the Clarion Project a non-profit 
organization that has archived Islamic State propaganda as part of its efforts to "educate the public about the dangers of radical Islam" (Clarion Project, web ). The Islamic State started publishing its first online English magazine Dabiq in July of 2014 after the need arose for "a periodical magazine focusing on issues of tawhid (Oneness/ monotheism/unity), manhaj (doctrine), hijrah (seeking refuge), jihad (struggle), and jama'ah (togetherness/unity)" (Dabiq, Issue 1). The Dabiq was discontinued in July of 2016 and replaced by Rumiyah that was in publication from September 2016 to September 2017.

I use text analysis to determine the frequency with which categories of interest appear and create a network of terms that are used in tandem with the words of interest to give a better insight into the Islamic State's self-legitimation and use of selective language. The coding is both descriptive and interpretive as I combine qualitative and quantitative content analysis methods for my analysis. The quantitative content analysis helps to point out the most prominent terms that the Islamic State uses to legitimate itself. The qualitative content analysis helps to provide a deeper insight into the textual content of the magazines.

\section{Results and Discussion}

As a group claiming to act in the name of God in fulfilment of a prophecy, it comes as no surprise that "Allah" is the most frequent word I both issues of Dabiq and Rumiyah. In the first article of Issue 1 of Dabiq, Islamic State leader Abu Bakr al-Baghdadi is quoted saying;

“The earth is Allah's. \{Indeed, the earth belongs to Allah. He causes to inherit it whom He wills of His servants. And the [best] outcome is for the righteous\} [Al-A'raf: 128]. The State is a state for all Muslims. The land is for the Muslims, all the Muslims. O Muslims everywhere, whoever is capable of performing hijrah (emigration) to the Islamic State, then let him do so, because hijrah to the land of Islam is obligatory" (Dabiq 1, 11). 
If the earth belongs to Allah, then the Islamic State can take over whatever portion of it that the group desires.

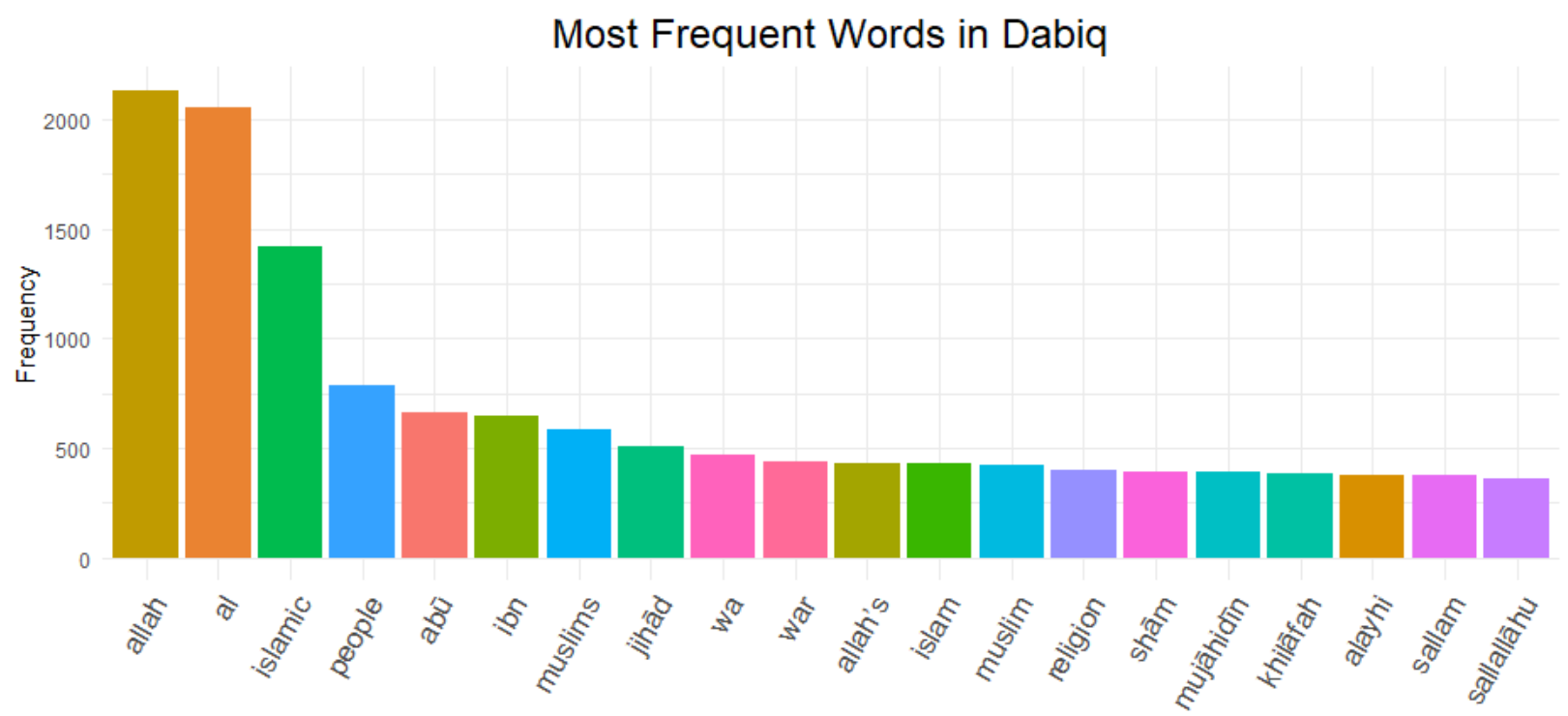

Most notable among the most frequent words are the; "jihad, war, mujahidin, khilafah, soldiers and killed". The emphasis on jihad goes hand in hand with waging war against the enemies of Islam. The Islamic state asks the "muwahhid, to defend the Islamic State. Dozens of nations have gathered against it. They began their war against us at all levels. So rise $\mathrm{O}$ muwahhid. Rise and defend your state from your place wherever you may be" (Dabiq, Issue 3). For the leaders of the Islamic State, "jihad [is] more obligatory and urgent than spending an unknown number of years studying while exposed to doubts and desires that will destroy their religion" (Dabiq, Issue 3). While waging jihad, Islamic State soldiers are encouraged to "kill a disbelieving American or European - especially the spiteful and filthy French - or an Australian, or a Canadian, or any other disbeliever from the disbelievers waging war, including the citizens of the countries that entered into a coalition against the Islamic State, then rely upon Allah, and kill him in any manner or way however it may be “ (Dabiq, Issue 4) 


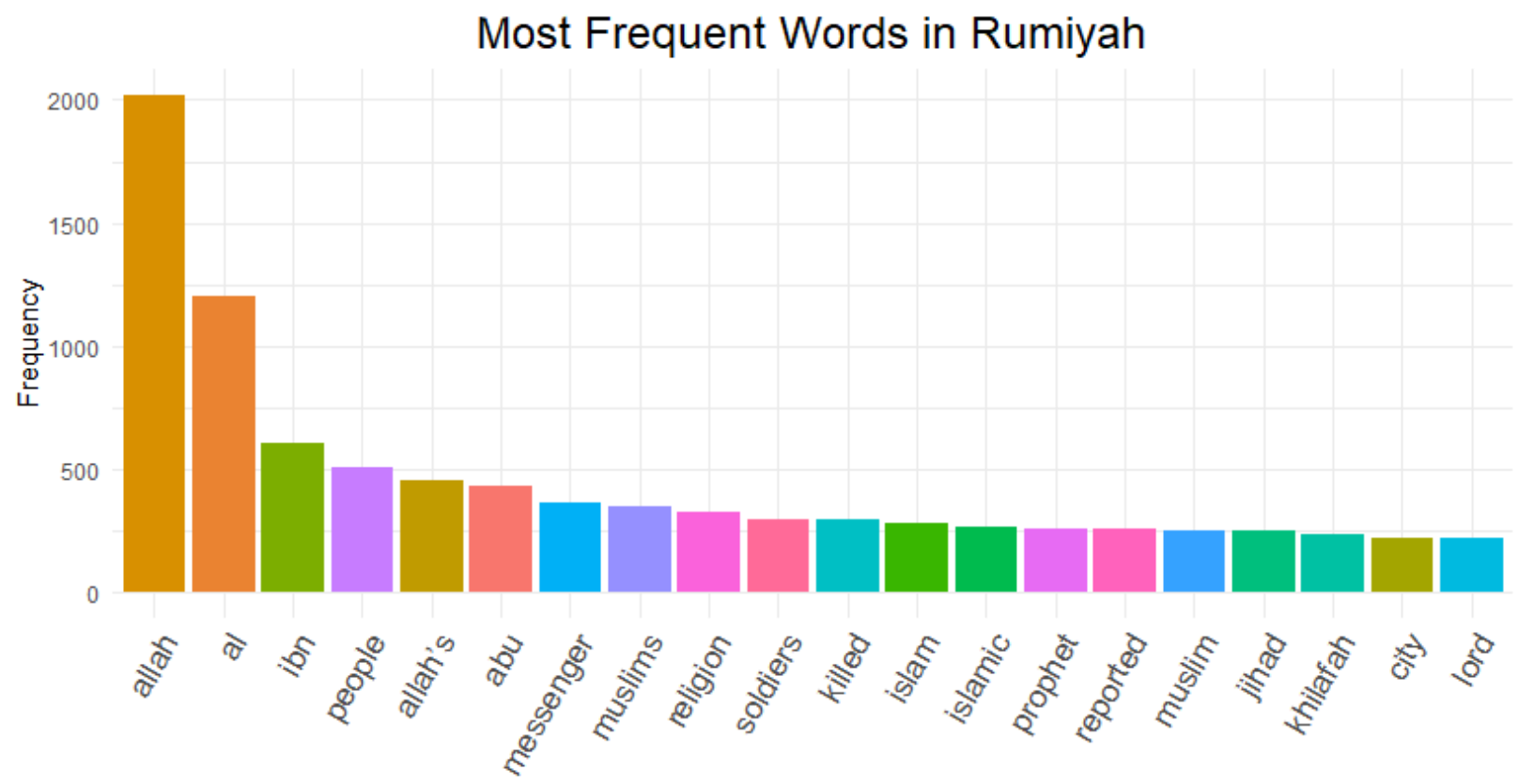

The difference between the most frequent words in issues of Dabiq and Rumiyah is the inclusion of the words "soldiers and killed." This is an indicator of the losses that the Islamic State was incurring during the writing of issues of Rumiyah. The first Issue of Rumiyah opens with the announcement of the killing of Islamic State leader Zarqawi and the issue continues documenting other killings that the organization has incurred. Despite all those killings, the Islamic State continues to encourage its constituents by reassuring them that all their efforts are not for nothing. In Issue 1 of Rumiyah, soldiers are reminded that 'those who were killed for Allah's cause as dead- rather, they are alive. They are provided for with their Lord, rejoicing in what Allah has bestowed upon them of His bounty, being cheerful of those who have yet to join them, that they shall have no fear, nor shall they grieve; cheerful of a blessing and grace from Allah and that Allah will not let the reward of the believers be lost" (Rumiyah, Issue 1:3).

The reference to Allah, religion, khilafah, jihad and Islam invokes religious symbolism and expertise. Expert knowledge of the Islamic State is evident in statements that show the Islamic 
State as the only authority legitimized by Allah to carryout the prophetic promises of prophet Mohammed. The Islamic State also emphasizes its religious and spiritual superiority in comparison to other radical jihadist groups like Al-Nusra and other Islamic Nations like Jordan. This expert knowledge is further substantiated by the quotation of Hadiths from the Quran and the explanation of Islamic religious texts to the reader.

The reference to soldiers, war and killed invokes the Islamic State's material capabilities. Capacity of the Islamic State to deliver desired results to its constituents is envisioned in the organization's military power in relation to its enemies both local and international. The Islamic State uses its propaganda magazines to communicate its achievements for example the killing of enemy soldiers, battles won, and territories captured. For example, Issue 6 of Rumiyah reports the events of the battle with Nusayriyyah (A shi'ite jihadi group). Part of report states that "The soldiers of the Khilafah [Islamic State] took complete control of Mount Huyan, the Talilah checkpoints, and a number of checkpoints located further forward in the areas surrounding the silos during the course of the first day of battles, and all praise is due to Allah" (Rumiyah, Issue 6:36).

\section{Charts showing the topic models in Dabiq}




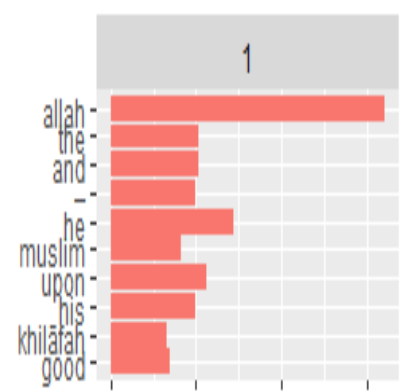

$\begin{array}{llll}0.00 & 0.01 & 0.02 & 0.03\end{array}$
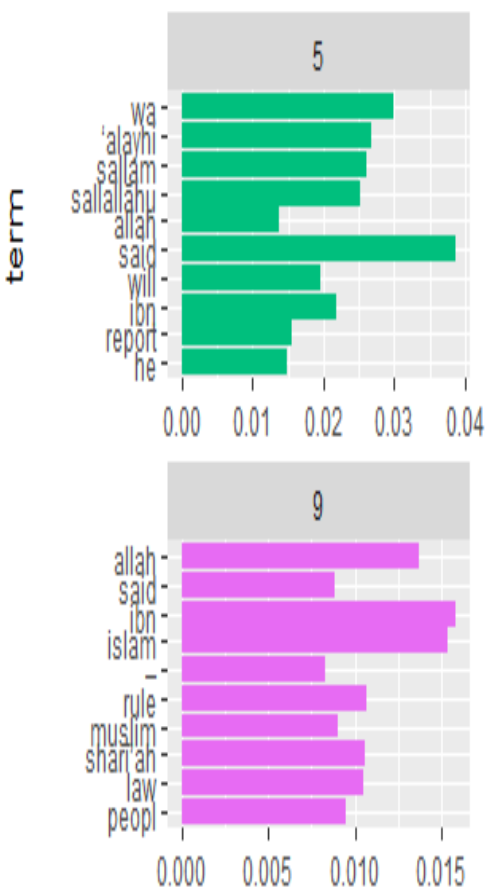

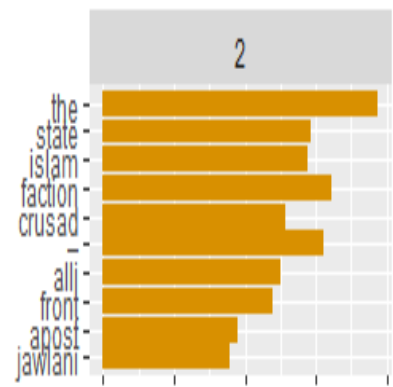

$\begin{array}{lllll}0.000 & 0.005 & 0.010 & 0.015 & 0.020\end{array}$

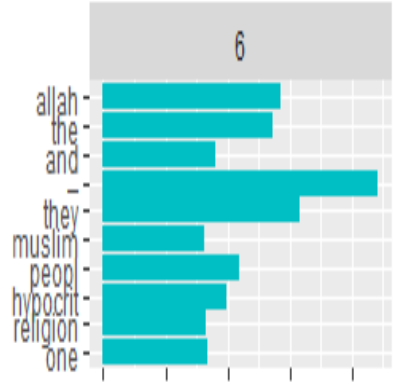

0.0000 .0050 .0100 .0150 .020

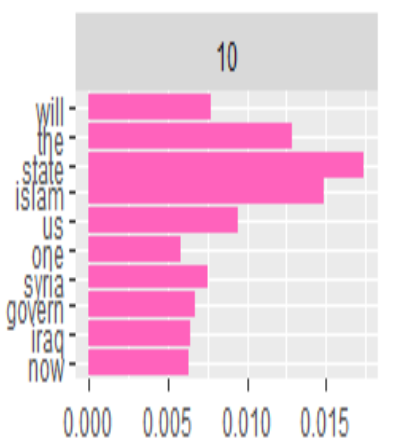

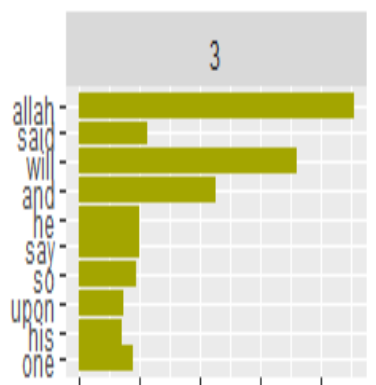

$\begin{array}{llllll}0.00 & 0.01 & 0.02 & 0.03 & 0.04\end{array}$

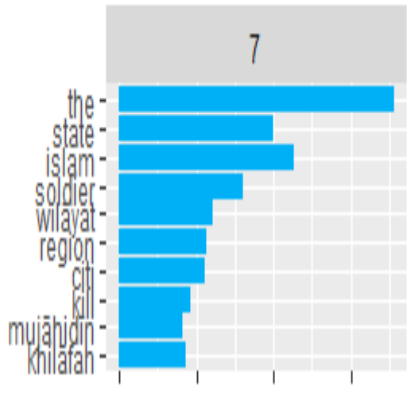

$\begin{array}{llll}0.00 & 0.01 & 0.02 & 0.03\end{array}$
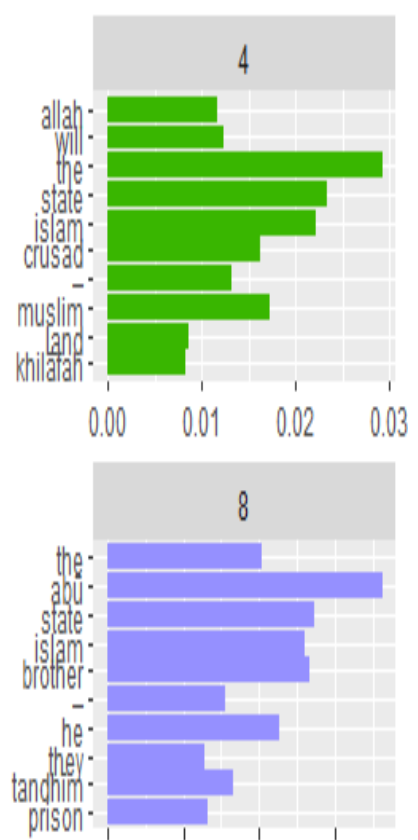

$\begin{array}{llll}0.000 & 0.005 & 0.010 & 0.015\end{array}$

\section{Charts showing the topic models in Rumiyah}




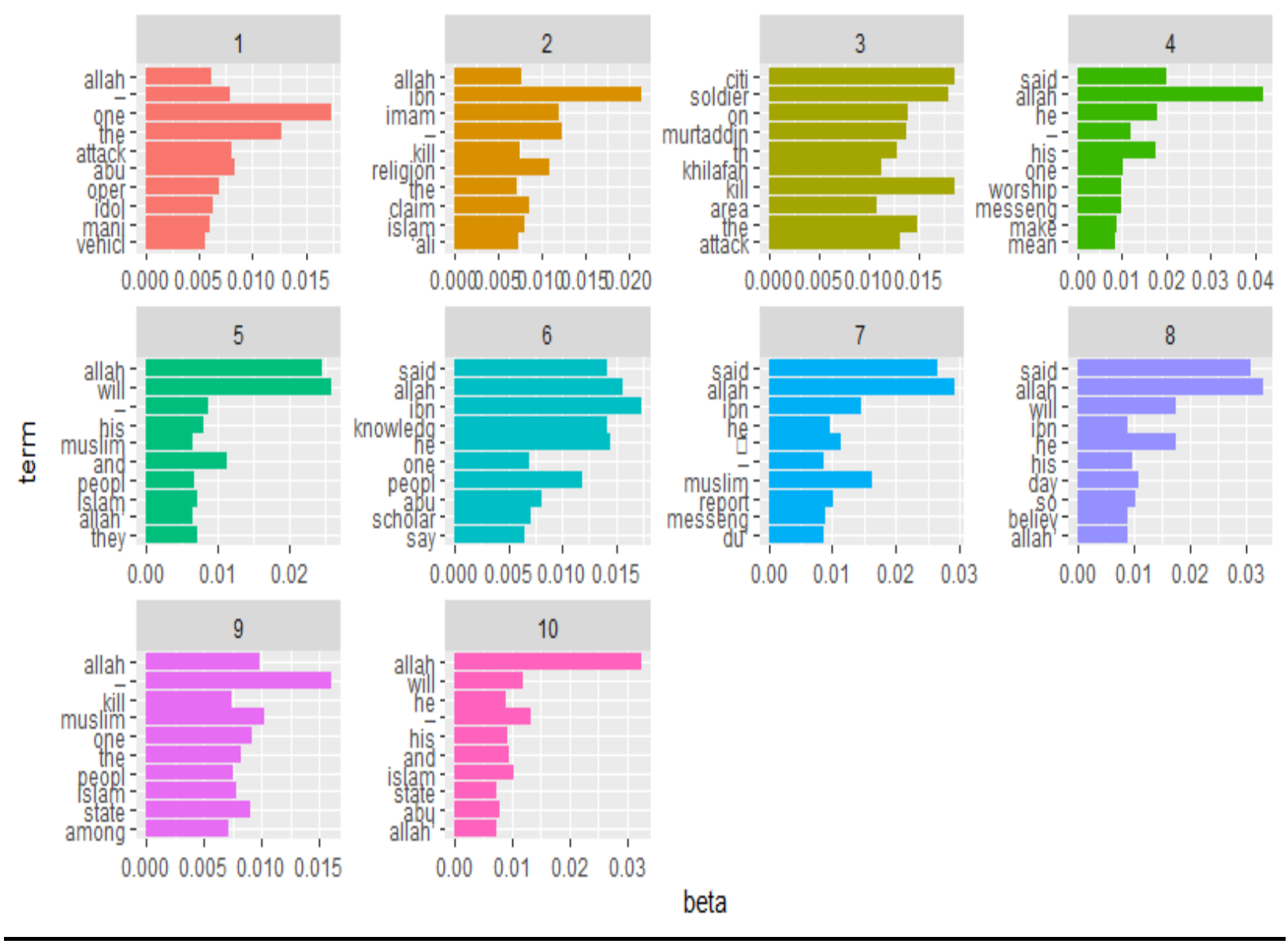

Looking at the topic models, provide an extensive and better view at the topics within the magazines beyond the most frequent words. If we look at topic 2 , we can see some of the organizations that the Islamic State was fighting against for example the al-Nusra Front, Jawlani, crusaders (referring Western states and their allies), apostate governments (Middle Eastern governments). These topics indicate recurrent themes in issues of Dabiq Magazines. The Beta value allows for the control of topic similarity. A low beta value indicates that topics are distinct and therefore will make words that appear fewer and are more unique within a document to belong to each topic. Conversely, a high beta value will indicate topics that have more words in common. 


\section{Conclusion}

In this paper, I use evidence from Islamic State English language propaganda magazines to study the different ways that the group legitimated itself to its target audience. I find that, the most prominent topic and words in the magazines substantiate the Islamic State's claim of establishing a Muslim caliphate as prophesied by the prophet Mohammed. One thing becomes clear as one goes through the magazines, Islamic State leaders knew that they could not do it alone and urged its members to "gather [themselves] and support [their] state, for [they] depend on it and it depends on [them]" (Dabiq, Issue 4). Issues of the propaganda magazines are riddled with strategies guiding those who pledge allegiance to the group in how to conduct themselves. There is a realization that it takes collective effort to make this Muslim caliphate a reality.

\section{Works Cited}

Applbaum, Arthur. 2010. Legitimacy the Duty to Obey. Philosophy \& Public Affairs.

A Arjona, N Kasfir, Z Mampilly. 2015. Rebel Governance in Civil War. Cambridge University Press.

Atwan, Abdel. 2015. Islamic State: The Digital Caliphate. University of California Press. Benmelech, Efraim and Esteban F. Klor. forthcoming. "What Explains the Flow of Foreign Fighters to ISIS?” Terrorism and Political Violence .

Bloom, Mia, Hicham Tiflati and John Horgan. 2017. "Navigating ISIS's preferred platform: Telegram." Terrorism and Political Violence

Boix, Carles. 2008. "Economic Roots of Civil Wars and Revolutions in the Contemporary World.”World Politics 60:390-437

Borch Guri and Stuvoy, Kristi. 2011. Practices of Self-Legitimation in Armed Groups: Money and Mystique of the Farc in Colombia. Distinktion: Scandinavian Journal of Social Theory. 
Bröckling, Micha et al. 2018. "Kill Them Wherever You Find Them" - Radicalizing Narratives of the "So-Called" Islamic State Via the Online Magazine Rumiyah. Journal for Deradicalization, (17): $240-294$

Byman, Daniel. 2016. "Understanding the Islamic State - A Review Essay"

Byman, Daniel.2015. Al Qaeda, The Islamic State, And the Global Jihadist Movement: What Everyone Needs to Know. Oxford University Press.

Cederman, Lars-Erik, Nils B. Weidmann, and Kristian Skrede Gleditsch (2011), Horizontal Inequalities and Ethnonationalist Civil War: A Global Comparison, in: American Political Science Review, 10503, 478-495.

CNN. 2019. ISLAMIC STATE Fast Facts. https://www.cnn.com/2014/08/08/world//slamic Statefast-facts/index.html

DeCilia, Brooks. 2o19. Global Public Sphere. http://www.Ise.ac.uk/media-andcommunications/events/past-events/the-global-public-sphere

Duyvesteyn, Issabelle. 2017. Rebels \& Legitimacy: An Introduction. Small Wars \& Insurgencies.

Eriksen, Stein Sundstol and Sending, Ole Jacob. 2013. There Is No Global Public: The Idea of The Public and The Legitimation of Governance. International Theory

Fearon, James D., and David D. Laitin (2003), Ethnicity, Insurgency, and Civil War, in: American Political Science Review, 9701, 75-90.

Hurd, Ian. 1999. "Legitimacy and Authority in International Politics"

Mahood, Samantha and Rane, Halim. 2017. Islamist Narratives in ISISRecruitment Propaganda. The Journal of International Communication 23(1): 15-35.

Mahzam, Remy.2017. Rumiyah - Jihadist Propaganda \& Information Warfare in Cyberspace. Counter Terrorist Trends and Analyses, 9(3): 8-14

Mampilly, Zacharia. 2011. Rebel Rulers: Insurgent Governance and Civilian Life During War. Cornell University Press.

Mitts, Tamar. 2019. Countering Violent Extremism and Radical Rhetoric.

Varese, Federico. 2018. Mafia Life: Love, Death and Money at the Heart of Organised Crime.

Terpstra, Niels and Frerks, Georg. 2017. Rebel Governance and Legitimacy: Understanding the Impact of Rebel Legitimation on Civilian Compliance with the LTTE Rule. Civil Wars.

Sullivan, John P. and Robert J. Bunker. 2002. "Drug Cartels, Street Gangs, and Warlords" 
Tilly, Charles. 1985. "War Making and State Making as Organized Crime"

Weber, Max. 1918. "Politics as a Vocation"

Thomson, Janice. 1994. Mercenaries, Pirates, Sovereigns: State-Building and Extraterritorial Violence in Early Modern Europe

Ryall, David. 2001. "The Catholic Church as a Transnational Actor"

Sanders, Lynn. 1997. Against Deliberation. Political Theory

Scudder, Mary. 2019. The Ideal Uptake in Democratic Deliberation. Political Studies.

Simmons, John. 1999. Justification and Legitimacy. Ethics

Steffek, Jens. 2003. The Legitimation of International Governance: A Discourse Approach. European Journal of International Relations.

Suchman, Mark. 1995. "Managing Legitimacy: Strategic and Institutional Approaches." Academy of Management Review 20:571-610.

Symons, Jonathan. 2011. The Legitimation of International Organizations: Examining The Identity of The Communities That Grant Legitimacy. British International Studies Association 27:2557-2583.

\section{Primary Sources}

Dabiq. (2014a). Dabiq issue 1.

Dabiq. (2014b). Dabiq issue 2.

Dabiq. (2014c). Dabiq issue 3.

Dabiq. (2014d). Dabiq issue 4.

Dabiq. (2014e). Dabiq issue 5.

Dabiq. (2014f). Dabiq issue 6.

Dabiq. (2015a). Dabiq issue 7.

Dabiq. (2015b). Dabiq issue 8.

Dabiq. (2015c). Dabiq Issue 9. 
Dabiq. (2015d). Dabiq Issue 10.

Dabiq. (2015e). Dabiq Issue 11.

Dabiq. (2015f)Dabiq Issue 12.

Dabiq. (2015g). Dabiq Issue 13.

Dabiq. (2015h). Dabiq Issue 14.

Dabiq. (20151). Dabiq Issue 15

Rumiyah. (2016a). Rumiyah issue 1.

Rumiyah. (2016b). Rumiyah issue 2.

Rumiyah (2016c). Rumiyah issue 3.

Rumiyah. (2016d). Rumiyah issue 4.

Rumiyah. (2017a). Rumiyah issue 5.

Rumiyah. (2017b). Rumiyah issue 6.

Rumiyah. (2017c). Rumiyah issue 7.

Rumiyah. (2017d). Rumiyah issue 8.

Rumiyah. (2017e). Rumiyah issue 9.

Rumiyah. (2017f). Rumiyah Issue 10.

Rumiyah. (2017g). Rumiyah Issue 11.

Rumiyah. (2017h). Rumiyah Issue 12.

Rumiyah. (2017i). Rumiyah Issue 13. 
Aweko 25 